\title{
37. 慢性中耳炎による骨導閾值の変化
}

\author{
赤井貞康・矢吹今日子・小寺一興・鈴木淳一（帝京大）
}

目的 中耳の長期間の炎症により，内耳障害が生じ 万危険性が考えられている。本研究では，慢性中耳炎 にともなう内耳障害の有無を, 病型別ちよび年秢別に 検討することを目的とした。

对象と方法一側性慢性中耳炎425例を対象とした。 健側の耳の条件は, 鼓膜に病的な所見がなく, 気骨導 差が $15 \mathrm{~dB}$ 以内とした，外傷性鼓膜穿孔例は除外した。 病型別の内訳は, 中心穿孔性中耳炎180例，上鼓室型真 珠腫 ( $\mathrm{M}$ 型真珠腫之略す) 142例, 後上象限型真珠腫㧈

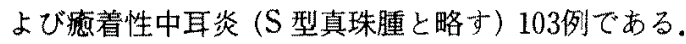
一側性慢性中耳炎症例の健側と患側の骨導閶値差を, $500 \mathrm{~Hz}, 1000 \mathrm{~Hz}, 2000 \mathrm{~Hz}, 4000 \mathrm{~Hz}$ の各周波数につい て求め，その 4 周波数の平均が $20 \mathrm{~dB}$ 以上の症例を骨 導闘值上昇例とした。な招骨導闘值は，健側ではマス キングなしの骨導闇唒，中且炎側では健側耳をバンド

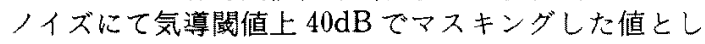
た。

結果 1) 一側慢性中耳炎425例中33例7.8\%の症例 が，健側に比べて中耳炎側の骨導闇值の $20 \mathrm{~dB}$ 以上の
上昇を認めた，2）骨導閔值上昇を生じる頻度は, 加龆 とともに上昇する傾向がみられ，20歳未満群に比べて 30 歳以上の群で有意な差を認めた $(\mathrm{P}<0.01)$. 3) 骨導 閾值上昇を生じる頻度は, 中心穿孔性中耳炎180例中 8 例 $(4.4 \%), \mathrm{M}$ 型真珠腫 142 例中11例 $(7.7 \%), \mathrm{S}$ 型真 珠腫103例中14例 (13.6\%)であり，中心穿孔性中耳炎 と $\mathrm{S}$ 型真珠腫との間に有意な差を認めた $(\mathrm{P}<0.01)$.

4) 中心穿孔性中耳炎およびM型真珠腫にちける骨導 閾值上昇例の頻度は，周波数間の差異を認めなかった が, $\mathrm{S}$ 型真珠腫においては, $1000 \mathrm{~Hz}, 2000 \mathrm{~Hz}, 4000 \mathrm{~Hz}$ の高周波数域の頻度が，低周波数よりも増加していた。 5） S 型真珠腫において骨導閾值上昇例の頻度は, あ心゙ み骨上部構造の破壊例が33例中 6 例 $(18.2 \%)$ ，あぶみ 骨健在例が70例中 8 例 $(11.4 \%)$ であり，前者の頻度 が高かったが，有意な差ではなかった。

結語 慢性中耳炎は, 特に S 型真珠腫において, 加 齢とともに高周波数域より骨導闘値の上昇を生じる危 険が高くなり，早期に治療することが望ましい.

\section{8. エンドトキシンの正円空膜透過性について}

\author{
飯野ゆき・鳥山 稔(国立医療センター) \\ 金ヶ崎士朗 (東大医科研) 志賀淳治（東大・病理）
}

はじめに慢性中耳炎における骨導低下の原因とし てエンドトキシンなどの菌体成分が内耳障害を引き起 こしている可能性が示唆されている。ててで私どもは, 実験動物の中耳腔にエンドトキシンを投与し正円空膜 の変化と外リンパ空への移行に関して検討した。

実験方法 白色モルモット80れを用いた。これらの 中耳腔に経鼓膜的に ${ }^{3} \mathrm{H}-$ Salmonella 死菌液 (4.88× $\left.10^{6} \mathrm{dpm} / \mathrm{ml}\right)$ ，またはこの Salmonella 加ら抽出した

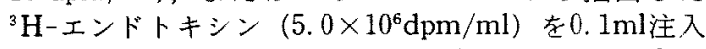
した。これらのエンドトキシン濃度は E. coli LPS 標準として $1-10 \mu \mathrm{g} / \mathrm{ml}$ であり，中耳炎の際に検出さ れる濃度とほぼ同程度である。注入後経時的に中耳骨 胞を摘出しパラフィン切片を作成し，オートラジオグ ラフィーにて観察した。また9匹のモルモットでは，

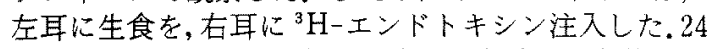
時間後に中耳骨胞を開放して中耳貯留液を回収後, 外 リンパ液(約 $5 \mu 1$ ) を採取した。これらの試料の radioactivity を湘定した。

結果 エンドトキシン投与後 2 時間では, 正円空膜 内の血管の拡張，出血がみられる。正円空膜内及び外 リンパ腔に back ground 以上の grain はみられなか った。投与後48時間では，正円空膜外層直下に多数の
好中球の浸潤がみられ，更に中耳腔に向かって遊走し ている像が観察された，また一部外層上皮の脱落して いる部位がありそのような膜内にわずかではあるが grainが存在していた。まれに外リンパ空にも中皮細 胞の間吵を好つて好中球が遮走し，grainが付着して いるのが観察されたが，活とんどの動物では外りンパ 腔に細胞浸潤や grain を認めなかった。また投与24時 間後に外リンパ液を採取しその radioactivityを溳定 したが，生食投与群と有意差はなかった。

まとめ1）中耳腔に投与したエンドトキシンが, 直 ちに外リンパ腔に移行する可能性は低い。2）正円空膜 は付着し侵入しようとするエンドトキシンに対して, 食細胞を遊走させ処理しうる生体防御機構を有する。 3）正円空膜の炎症が高度となり,外層上皮細胞が脱落 すると，エンドトキシンが外リン八舼に慢入しうる. 質問 田口喜一郎(信大)。エンドトキシンの分子量と 正円空膜透過性との関係はどうか。正円空膜上皮は破 壊してお透過性をみる実験を行ったか。行っていれ ばその成績について。応答 今まで三種のエンド トキシン $(\mathrm{Et})$ で実験している。死菌液, EDTA 抽出, フェノールウォータ一抽出である。前二者がより自然 な形の Et でほぼ同様の変化だったが,フエノールウ 